\section{Virology institute changes direction}

SIR - You reported recently (Nature 374, 299; 1995) my dismissal after almost eleven years as director of the Natural Environment Research Council (NERC)'s Institute of Virology and Environmental Microbiology (IVEM) in Oxford and less than three years before my retirement at 60 . The dismissal was on "Compulsory Early Retirement (structure) grounds" although the institute will continue with a new director, that is, the same organizational "structure".

You also reported that NERC senior management says this move followed an independent review of IVEM work carried out in line with government policy as laid down in Realising our Potential. The only review of which I am aware was chaired by Professor Roger Whittenbury. It met once in London (at the end of December 1994). There were no oral or written presentations of IVEM work or outside peer review. The only scientific information concerning IVEM, and provided by NERC, was copies of the institute's annual reports (latest 1992--94) listing highlights of recent research, in particular work sponsored by industry, government and the European Union. Following this meeting, the group reported to NERC a month or so ago, recommending that a new working group be established to define NERC's priorities in environmental microbiology and thereafter the role of IVEM. The Whittenbury group did not make any detailed or substantive comments about the NERC research at the institute, or recommend a new mission or my dismissal. The most recent council mandated review of IVEM science and management (Science and Managament Audit) involved a visiting group to the institute at the end of 1990. This was chaired by Professor Anne Warner, and its recommendations were implemented in full over the following 2-3 years. The next review was scheduled for the end of 1995.

NERC states that following a recent independent review, council decided to change the IVEM mission. Arguably, the new IVEM mission is wholly incorporated in the IVEM mission previously established by council and which the institute has implemented. I was told that "Council considers that this will require a new scientific leadership with capabilities for which you are unsuited".

There was no meeting of council to set aside the previous mission, to agree a new mission, to establish a working group, or to take a view about priorities in environmental microbiology, the IVEM science, the leadership required or my suitability. There was no notice or prior discussion with me of either a new mission or my termination of service. No established procedure or due process has been followed.

\section{David H. L. Bishop}

8 Carey Close,

OxfordOX13SR, UK

\section{Slow but steady}

SIR - Although Daedalus usually describes new ventures likely to be successful, a recent proposal (Nature 373, 108; 1995) was partially applied long ago and proved unsuccessful. His forest factory contains tree trunks force-fed with a basal pressurized mineralized solution and branch terminals are alternately sucked to extract water and then pressurized with glucose solution to simulate circadian sap flow. He predicts "cheap and perfect factory timber" that grows "with amazing speed".

At the time when Great Britain obtained possession of the Cape of Good Hope in the early nineteenth century, many oak trees were necessary for the men-of-war of the Royal Navy, upon which the nation's power principally depended. In Britain oaks required three centuries or more to mature, and even then existing British forest supplies were recognized as needing replenishment. The Cape's climate was far more clement than Britain's and oaks were observed to grow there very rapidly, with projected ages at maturity of 80 or so. Oaks were planted in appropriate parts of Cape Town and surrounding regions, notably Stellenbosch, the second oldest settlement in the province. (This town still is known as Eikestad or the Town of Oaks). The oaks grew as rapidly as anticipated, so confirming Daedalus' deduction of the consequences of increased glucose production and mineral/water availability. Alas, the mature trees produced wood of grossly inferior quality, quite unsuitable for ships. But fortunately for the Royal Navy, steel had replaced oak in ship construction by that time. So advantages of controlled factory growth of trees probably do not include shorter times to maturity. Daedalus's forest factory should perhaps therefore be a long-term project, without force feeding.

\section{S. Wynchank}

Medical Research Council,

Parow, South Africa

\section{Marcus Marci}

SIR - This year we celebrate the 400th anniversary of the birth of Ioannes Marcus Marci of Kronland. He is known to have been an outstanding scientist at University in Prague during the first half of the seventeenth century. His scientific activi- ties covered, besides medicine and physics, mathematics, astronomy and philosophy, and 16 books were published in Prague, nine of them written during the Thirty Years' War.

Marcus Marci was born on 13 June 1595 in the town of Lanškroun in eastern Bohemia. After studying philosophy and theology at Olomouc Jesuit College he received the degree of philosopher in 1615 , adding the title Boemus to his name to stress his Czech origin. In 1625 , he was granted the degree of doctor of medicine, and subsequently received further honours. He was an official physicist of the Czech Kingdom and personal physician of the Emperor Ferdinand III and the Czech King Leopold I.

Marci wrote the first medical books written and published in Bohemia. In De proportione motus seu regula sphygmica ("About a proportion of motion or the impact rule") (1639), he described the laws governing impact of spherical bodies. $\mathrm{He}$ published the results of his investigation of light properties in Thaumantias. Liber de arcu coelesti deque colorum apparentium natura ortu et caussis (see ref. 1). The results of his investigations marked a significant advance in physics ${ }^{2}$ that was much later continued by Newton, Huygens and others. Already before 1639 , Marci had realized that the period of a pendulum's oscillations is proportional to the square root of its length.

Marci had been working at the Prague University during an extremely difficult time. The Czech Protestant nobility was emigrating as a consequence of the defeat after the battle at White Hill (1620), a prelude to the horrors of the Thirty Years' War (1618-48). Despite these complicated times, Marci remained loyal to his Czech origins.

Since 1977 the "Ioannes Marcus Marci of Kronland Medal" has been awarded in recognition of achievements in spectroscopy. Marci is also among the names of scientists given to the craters on the Moon.

\section{Miloslav Vobecký}

Academy of Sciences of Czech Republic, Institute of Analytical Chemistry,

Prague, Czech Republic

1. Marek, J. Nature 190, 1092 (1961)

2. Mach, E. Die Mechanik in ihrer Entwicklung 310-313 Brockhaus, Leipzig, 1933).

\section{Alive and shopping}

SIR - "One of those to return from the war was the late Maurice Pryce. . ." says John Maddox (Nature 374, 211; 1995).

When I met Maurice Pryce dashing around Safeway the other day I couldn't help thinking he wouldn't often be late.

\section{G. R. Walker}

4714 W 7th Street

Vancouver, Canada V6T 1C6 